\title{
Erich Fromm: ke kořenům etiky
}

\section{Pavel Žd'árský}

Envigogika 2008/III/1 - Recenzované články/ Reviewed Papers

Publikováno/Published 21. 05. 2008

DOI: http://dx.doi.org/10.14712/18023061.28

\begin{abstract}
Abstrakt:
Článek je zaměřený na Frommovu nenáboženskou, psychologicky pojatou interpretaci židovsko-křest́anské tradice o dvou cestách člověka. Jde o upravenou verzi článku publikovaného v e-journalu PAIDEIA 2/2005, www.pedf.cuni.cz/paideia.
\end{abstract}

\section{Klíčová slova:}

Etika, židovsko-křestáanská tradice, biofilní a nekrofilní orientace člověka

\begin{abstract}
:
The article is focused at Fromm's nonreligious, psychologically conceived interpretation of the Jewish-Christian tradition on two potential life directions of any individual. Fromm's separation from religious practice was simultaneously compensated by an attempt to create a new, unreligious rewording of the tradition of his nation, which in many aspects stayed close to the content of Jewish tradition. It is for example apparent in his differentiation of the biophilious and necrophilious orientation of a man. A man who doesn't sensibly unfold his relation towards the world in active biophilious manifestation remains underdeveloped and his unfulfilled yearning for fulfillment in life is easily turned in a destructive direction.
\end{abstract}

\section{Key words:}

Ethics, Judeo-Christian tradition, biophilious and necrophilious orientation of man 
Toto praví Hospodin: Hle, předkládám vám cestu života a cestu smrti. $($ Jr 21,8)

Erich Fromm vyrůstal v intelektuálním židovském prostředí. Obklopen znalci Zákona sám v dětství toužil stát se učitelem talmudu. Přestože v mládí přešel na neteistické stanovisko, byl jeho humanismus již orientován. Vyrůstal z kořenů pevně vetknutých v rodinném zázemí rabínských výkladů o pravdě, spravedlnosti, lásce a přitakání životu, $v$ tradici, $v$ níž je úkolem člověka směřovat $k$ plnějšímu lidství. Klinická praxe psychoanalytika později dodala těmto ideálům empirický základ a Frommovi možnost formulovat argumenty. ${ }^{1}$

Vedle náboženských kořenů se tedy musel vyrovnat s odkazem Freudovým. A bylo tu ještě dílo další nepřehlédnutelné postavy, které zanechalo ve Frommově myšlení viditelný otisk: Karla Marxe. ${ }^{2}$ Ve výčtu hlavních zdrojů Frommových prací pak není možné vynechat jeho sympatie $\mathrm{k}$ buddhismu a mystikům.

Frommův rozchod s náboženskou praxí byl zároveň kompenzován pokusem o nové, nenáboženské přetlumočení tradice jeho národa, které $v$ mnoha ohledech zưstalo duchu židovského dědictví blízké. ${ }^{3}$ Věnujme toto krátké ohlédnutí jednomu z aspektů Frommova díla, kde je tato blízkost žrejmá.

\section{Dva sklony, dvě orientace}

Člověk je v rabínském pohledu vybaven dvěma základními pudy, jecerim. Fromm odvozuje slovo jecer od základu j-c-r, formovat, utvářet - "jako hrnčir hliněnou nádobu". Substantivum se dá přeložit jako forma a v psychické souvislosti též slovy imaginace, nástroj, účel. Pro Fromma tak hebrejský pojem pro pud vyjadřuje rovněž "představivost" - dobra nebo zla (Fromm 1993: 119). Dva základní sklony představují alternativy lidské volby, do které Bůh nezasahuje. Jen málo lidí, upozorňuje Fromm, je v židovském pohledu "spravedlivých", kteří již ztratili svobodu volit zlo. Jen u menšiny převládají zlé snahy. Většina lidí je uprostřed a síly obou sklonů mají víceméně vyrovnané. (Fromm 1993: 123)

Podle Fromma je člověku vrozená biofilní orientace a uskutečňuje se jako primární potencialita jeho jednání. Lidský druh ve vývoji instinktů zaostal za rychlostí dějin. Fromm to ovšem nevidí jako problém. Člověk se stal vývojem jiným co do pudové výbavy, než jsou zvířata: „„...čím více se člověk vyvíjel, tím méně se u něj objevovalo geneticky zakódovaných adaptivních změn, a v posledních čtyřiceti tisících letech už nenastaly žádné." (Fromm 1997a: 252) Nedostatky v pudovém vybavení pro reakce na svět však nejsou podle Fromma problémem vzhledem ke specifikům lidského druhu a jeho evoluce, protože u člověka je nahrazuje charakterová struktura. Charakterová struktura doplňuje slabě vyvinuté lidské instinkty a je "druhou přirozeností člověka". Podněty k chování bývají často nevědomé a jsou integrované v charakterové struktuře (Fromm 1997a: 17nn).

Fromm vedle instinktivismu ostře kritizuje i teorii prostředí. Člověk se podle ní rodí dobrý a rozumný. Když se u něho vyvinou zlé sklony, jsou na vině špatná společnost,

\footnotetext{
${ }^{1}$ Viz Funk (1994). Kromě rodinného zázemí to bylo studium talmudu. V jeho humanistické interpretaci Fromma silně ovlivnil např. rabi Salman Baruch Rabinkow.

2 k Frommovu hodnocení Marxe především jeho kniha Marx's Concept of Man (česky 2004).

${ }^{3}$ Srv. Löwy (2001). Löwy řadí Fromma do jednoho z proudů židovské utopické kultury střední Evropy spolu s Freudem a Marxem, vedle př́stupu Martina Bubera. S Buberem má ale podle něho Fromm společné základy $v$ biblickém proroctví a $v$ chasidismu. Marxovu filosofii měl Fromm chápat jako „prorocký mesianismus, vyjadřovaný světským jazykem". Přes ztrátu víry Frommovo myšlení "bude vždycky silně poznamenáno náboženskou spiritualitou". Srv. Štampach (1999). Fromm podle Štampacha patř́ k autorům opravdového dialogu. Židovskou tradici vykládal v křestáanském kontextu a vystupoval proti náboženské nesnášenlivosti.
} 
výchova a př́klady (Fromm 1997a: 46). Člověk se však podle Fromma nerodí přímo dobrý či zlý, ale se dvěma sklony, dvěma potencialitami: „Věří-li někdo v dobrotu člověka jako $v$ jeho jedinou možnost, musí nutně přibarvovat skutečnost na rưžovo, což vyústí nakonec $v$ trpkou deziluzi. Věrí-li někdo $v$ druhý extrém, skončí jako cynik a bude slepý k mnoha možnostem dobra $v$ druhých i v sobě samém. Realistický pohled vidí obě možnosti jako reálné potenciality..." (Fromm 1969: 101) Fromm zároveň rozlišuje pozici obou sklonů. Je-li všemu živému vrozená tendence růst a rozvíjet se, tedy „primární potencialita", v člověku jakkoliv zablokována, obrátí se její energie destruktivním směrem a prostor získá "potencialita sekundární" (Fromm 1967: 170n).

Charakterem podmíněné vášně se podle Fromma nevyskytují osamoceně, ale v rámci celých syndromů. Fromm rozlišuje "život podporující syndrom" a "syndrom životu nepřátelský". V drtivé většině je možné u průměrných lidí najít jejich směs. "Pro chování člověka a pro jeho možnost změnit se je rozhodující relativní síla obou syndromů." (Fromm 1997a: 253n) Člověk je tedy orientován bud' "biofilně" nebo „nekrofilně". ${ }^{4}$ Není biologicky navždy determinovaný, ani od přirozenosti jen zlý či nenávratně zkažený, má mravní odpovědnost kvưli své schopnosti volby a změny.

V židovsko-křestáanské náboženské terminologii se změna, obrat, uskutečňuje v lidském srdci, které není jen tělesným orgánem ale centrem cítění i myšlení, kde vznikají základní volby člověka, odkud pramení jeho směřování a jednání. Fromm se tomuto výrazu nevyhýbá, ale $v$ jeho odborné psychologické práci lidské srdce nahradil pojem charakterová struktura. Její změna je mu základním imperativem tváří v tvář záhubě. 5

Změna má nastat v charakterové struktuře, která, jak jsme viděli výše, podle Fromma člověku nahrazuje nedostatečné pudové vybavení: „Je to specifická struktura, v níž je organizována lidská energie, aby člověk mohl sledovat určité cíle; motivuje chování podle právě převládajících cílů. Ríkáme, že někdo reaguje ,instinktivně', když jedná tak, jak mu napovídá jeho charakter. Řečeno s Hérakleitem, charakter je lidským osudem."6

Fromm ostře odmítá sociobiologické zdůvodnění lidského jednání, např. u Konrada Lorenze. Chápe je jako morální relativismus, který umožňuje zdůvodnit jakoukoli vlastnost (třeba agresivitu) vrozenou, genetickou výbavou. Analogie mezi biologickými a sociálními jevy, mezi chováním lidí a zvířat, byt' i člověku nejbližších primátů, podle Fromma pokulhává. Kult genetiky je pro něho formou pohanství Fromm (1967: 177).

Fromm si uvědomoval ekologické hrozby. Jedním z důvodů "odumření našeho pudu sebezáchovy je drastičnost požadovaných změn". (Fromm 1992: 16) Toto odumření se projevuje „osudnou pasivitou" člověka a stejný princip je podle něho za chováním lidí, kteří odmítají lékařské vyšetření z obavy před diagnózou vyžadující radikální zákrok. Nedostatek lásky kživotu, nerozvinutá biofilní orientace, je problémem charakterové struktury. Podstatou ekologického ohrožení není pro Fromma nedostatečnost instinktivní výbavy člověka, ale povahových rysů.

Člověk se během svého vývoje vydělil z př́rody a překročil hranice pudového vybavení i tím, že začal rozvíjet své dispozice a vlastnosti, rozum a lásku. Jak ukazuje

\footnotetext{
${ }^{4}$ Fromm (1997a: 358n). Pojem nekrofilie je u Fromma širší, než pouze ve smyslu sexuální úchylky. $\mathrm{Na}$ rozdíl od Freuda obě tendence nejsou "stejného řádu" (vzhledem k Freudově teorii o jejich biologické danosti). Pro Fromma jsou dány charakterem a biofilie je vnímána jako normální stav, zatímco nekrofilie je "psychopatologickým jevem", "důsledkem zdušeného růstu, duševního zmrzačení".

${ }^{5}$ Fromm (1992: 15): „Poprvé v historii závisí fyzické přežití lidstva na radikální změně lidského srdce." (Zvýraznil Fromm.)

${ }^{6}$ Fromm (1997a: 251). Srv. str. 228n: „...charakter je relativně stálý systém všech neinstinktivních pohnutek, kterými se člověk vztahuje k lidskému i prírodnímu světu. Charakter můžeme chápat jako lidskou náhradu za chybějící zvířecí instinkt..." (Zvýraznil Fromm.)
} 
Fromm, stále více se tak odlišoval od zviřat. Používá složitěji rozvinutější inteligenci, sebeuvědomění a představivost nejen $\mathrm{k}$ uspokojování biologických potřeb, ale i k utváření orientačního rámce. Uvědomuje si zároveň svou odlišnost, nevědomost a omezenost, svou slabost. Život ostatních zvířat v prírodě se vyznačuje jakousi ", harmonií"; pudová výbava je dostačující a orientace v prostředí je samozřejmá a přirozená. Člověk se stal podle Fromma „anomáliî". Lidská pozice je paradoxní - překročili jsme hranice př́rody, i když jsme její součástí (Fromm 1997a: 227).

Tento konflikt si podle něho žádá řešení, odpověd', nestačí si ho jen uvědomit. V zásadě jsou podle Fromma možné jen dvě strategie. Regresivní odpověd' je pokusem zrušit vydělenost a dosáhnout jednoty návratem: $k$ prírodě, k živočišnému životu či předkům, návratem $\mathrm{k}$ předindividuálnímu stavu, ke stádnosti. To ovšem pro člověka znamená "skoncovat s tím, co jej činí lidským". (Fromm 1969: 96) Alternativou je řešení progresivní - problém lidské existence překonat dosažením nové jednoty a harmonie rozvojem vlastních sil, rozvinutím lidskosti (Fromm 1969: 97). Jinými slovy: nalezením tvưrčí, biofilní charakterové orientace, která se projeví jinou vztažeností. Ve všech lidských relacích, ke světu, bližním, k př́rodě, živočichům i věcem se uplatní láskou: "Láska je jedinou rozumnou a uspokojivou odpovědí na problém lidské existence." (Fromm 1997b: 126)

\section{Cesta smrti: nekrofilní orientace}

Fromm dospívá v otázce zla k podobnému řešení jako sv. Augustin: zlo nemá vlastní podstatu, je nedostatkem dobra, ve Frommově pohledu nedostatkem lidskosti; je „neúspěchem při realizaci života". (Fromm 1967: 171)

Jedním z hlavních motivů starozákonní tradice je odvrat od pohanských kultů, od uctívání model, od idolatrie. Čím byli kdysi členové pohanských panteonů, tím se současnému člověku staly „č̌est, vlajka, stát, matka, rodina, sláva, výroba, spotřeba a mají řadu dalších jmen". (Fromm 1993: 37)

Idolatrie, modlářství, se podle Fromma projevuje silnou vazbou člověka k čemukoliv, co ho dokáže zcela pohltit a čemu věnuje většinu času, úsilí, pozornosti, přemýšlení - vše se tak může stávat jeho skutečným bohem, resp. modlou, nezávisle na deklarované konfesi.

Zlo ve Frommově pojetí stále prohlubuje zmrzačení jeho nositele. Je smutným svědectvím promarněné cesty životem, která je důsledkem nesprávné odpovědi na otázku po smyslu existence: ,....zlo [...] působí opravdu ničivě na život, tělo i ducha, a to nejen na oběti, ale i na destruktivně se chovajícího člověka. (Destruktivita a krutost) Představují paradox: jsou životem, který se ve snaze mít nějaký smysl obrací sám proti sobě." (Fromm 1997a: 22)

Ve Frommově humanistické etice se člověk vrací $k$ sobě a jen sobě je i odpovědný za získání nebo promarnění života (Fromm 1967: 126-137). Etické normy podle Fromma spočívají na rysech, které jsou člověku bytostně vlastní a „jejich porušení vede k mentálnímu a emocionálnímu rozkladu". ${ }^{7}$ Autorita společnosti trvající na etických normách může sehrát jinou roli. Destruktivní člověk sice nebude jednat podle svého

\footnotetext{
7 Fromm (1967: 10). Srv. Fromm (1997a: 48n): „Máme mnoho psychologických důkazů, že úsilí o kreativitu a originalitu je $v$ člověku hluboce zakořeněné, a také $v$ oblasti neurofyziologie existují údaje naznačující, že úsilí o kreativitu a originalitu je "zabudováno" v našem mozku." Dále str. 258: „My však tvrdíme, že člověk má imanentní, vrozený a trvalý cíl..."
} 
charakteru, ale nezmění se. Jeho sklon „seschne”, ale nezmizí a v jiných podmínkách se může stát hrozbou (Fromm 1997a: 296).

Fromm vedle dichotomie mezi primární a sekundární potencionalitou, mezi biofilním a nekrofilním zaměřením, popisuje základní typy charakterových orientací. Ideálem jeho pojetí etiky je orientace tvưrčí, produktivní. ${ }^{8}$

\section{Cesta života: biofilní orientace}

Důležitou hodnotou ve starozákonní tradici, vedle odvratu od idolatrie, je ve Frommově interpretaci nápodoba Boha, imitatio Dei (Fromm 1993: 50nn). Ve Frommově neteistickém pohledu to znamená směřovat k nejvyšším ideálům, tak jak si je člověk začal $\checkmark$ průběhu dějin uvědomovat a racionálně zdůvodňovat. Směřovat $k$ nim podle něho předpokládá měnit sebe a jednat v souladu s nimi. Napodobovat Boha zároveň znamená „poznávat ho" (Fromm 1993: 53).

$\checkmark$ židovské tradici existuje několik centrálních hodnot. Nejsou to však podle něho izolované články doktríny, ale tvoři ucelený hodnotový systém. Jsou to "kladný poměr k životu, láska, spravedlnost, svoboda a pravda". (Fromm 1993: 133) Zásada ctít život je nejvyšší. (Fromm 1993: 21) Fromm se při výkladu židovské tradice dále dovolává chasidského komentáře ke Gn 1,31: „...člověk byl stvořen jako otevřený systém určený k růstu a vývoji..." (Fromm 1993: 134)

Život je Frommovi nejdůležitějším a zároveň nejtěžším uměním. V tomto umění má člověk zvláštní pozici: je umělcem a současně předmětem svého umění. Nejvlastnějším lidským cílem je rozvíjet se k tomu, co člověk potenciálně je (Fromm 1967: 18). Takový rozvoj, nebo jinak řečeno - seberealizace, má vést k aktivnímu projevování citových a rozumových schopností. Vrozeny je má každý, ale uskutečňují se podle Fromma jen do té míry, do jaké se vyjadřují. Rozvíjet svoji osobnost, být sám sebou a se sebou, Frommovi není samoúčelem, ale předpokladem, "aby se člověk dostal do vztahu k jiným". (Fromm 1967: 88)

Obdobné je i Frommovo chápání lásky. Láska není jen emoce, nebo zážitek zamilovanosti s biochemickými procesy, či pohlavní uspokojení, ani symbiotická závislost; láska je, stejně jako život sám, uměním, které je třeba si osvojovat (Fromm 1997b: 9-14). Láska předpokládá podle Fromma především aktivitu. Aktivita ve prospěch milovaného objektu je hlavním rysem lásky, jde o činný zájem o milovaného člověka (Fromm 1997b: 121n). Láska je životní postoj, orientace charakteru (Fromm 1997b: 49n). Je specifickým hodnotovým systémem, jehož nejvyšším cílem je růst a štěstí milovaného objektu, ale zároveň je způsobem životního zaměření milujícího člověka, který se s láskou vztahuje ke světu vůbec. Aktivní zájem o milovaný subjekt je spojený s jeho poznáním: "Láska je jediný způsob poznání, v němž akt spojení je odpovědí na mé hledání." (Fromm 1997b: 35n) Láska je pro Fromma paradoxem, v němž se dva stávají jedním, a přesto zůstávají sami sebou. Je možná, jen když se vztah dvou bytostí naváže z centra jejich existence. Není stavem klidu, ale neustálou výzvou a společnou prací (Fromm 1997b: 100).

Z poznání podle Fromma pramení další charakteristiky lásky, jako je úcta, odpovědnost a péče - napomáhání životu milovaného objektu, odpovědnost za jeho rưst. ${ }^{9}$ Láska je dáváním a pro produktivní zaměření charakteru je dávání zážitkem „zvýšené

\footnotetext{
${ }^{8}$ Srv. přehled a analýzu charakterových orientací Fromm (1967: 53-88).

9 romm (1997b: 32nn). Srv. Fromm (1967: 81). Fromm zde interpretuje Boží odpověd' Jonášovi: podstatou lásky je "pracovat pro něco", "dát něčemu vyrůst”. K odpovědnosti srv. str. 82: "Pocit odpovědnosti není žádnou povinností, která by byla člověku vnucována zvenčí, ale je mou odpovědí na to, o čem cítím, že se mne týká."
} 
vitality", která dávajícího naplňuje radostí. Dávání je výrazem životnosti. ${ }^{10}$ Lidské city přicházejí a odcházejí. Láska je víc než cit. Je to rozhodnutí, soud a slib (Fromm 1997b: $58 n)$.

Moderní společnost je údajně založena na sledování vlastního zájmu jednotlivcem. Ve skutečnosti je však podle Fromma postižena úpadkem skutečného zájmu člověka. Tím je právě návrat k sobě, vlastní změna a rozvoj svých sil, růst člověka k plnějšímu lidství (Fromm 1967: 111n). Láska tedy souvisí se schopností člověka vyvinout tvưrčí, produktivní orientaci vưči sobě i světu (Fromm 1997b: 115). Je to způsob chování, který může mít každý, pokud jeho myšlení a cítění není zmrzačeno: „Produktivní orientace osobnosti se vztahuje na základní způsob chování, totiž na to, jak se člověk uvádí ve všech oblastech lidských zkušeností do vztahů. Týká se duševních, citových a smyslových reakcí na druhé, na sebe sama a na věci." (Fromm 1967: 71)

Biofilní orientace je tedy obrácením ke světu. Člověk není jen mysl bez těla. Jako takový by mohl dosáhnout svého cíle čistě intelektuálním výkonem. Jako celek ducha a těla musí řešit problém své existence cítěním i jednáním, celým životem: "Musí usilovat o prožitek jednoty a jedinosti ve všech sférách svého bytí, aby nalezl novou rovnováhu. Proto uspokojující systém orientace vyžaduje nejen intelektuální, ale i citové prvky, které by se mohly realizovat akcí ve všech oblastech lidského snažení." (Fromm 1967: 42)

\section{Závěrem}

Není účelem tohoto textu, který je zaměřený pouze na Frommovu nenáboženskou, psychologicky pojatou interpretaci židovsko-křest́anské tradice o dvou cestách člověka, podat ucelený a kritický přehled Frommova myšlení. Stranou tedy zůstává mj. hlubší odpověd' na otázku, nakolik může být nenáboženský přístup k náboženské tradici smysluplný, zda neztrácí jeho psychologizující pokus transcendentální rozměr dialogu lidského individua $s$ tím, co ho přesahuje. Mưže být lidský život a rozvoj bez tohoto „buberovského napětí"? Představuje Frommem předkládaný lidský protějšek, TY ve formě jakéhosi neosobního $X$, dialog $s$ možným ideálním lidstvím, dostatečné ontologické zajištění etiky? Jaké omezující limity sama v sobě obsahuje humanistická etika?

Frommovo myšlení můžeme $v$ tomto ohledu charakterizovat citátem z talmudu, na který sám upozorňuje: „Kdyby jen opustili mne a dodržovali mou Tóru." (Fromm 1993: 32; jde o výrok JHVH v komentáři k Jr 16,11 v Pesikta de Rav Kahana) V éře po "smrti Boha" a nahrazování teologie antropologií je důležité, že můžeme být konfrontováni s duchem jednoho ze zdrojů naší civilizace - přes všechny slabiny a nedůslednosti takové interpretace - aniž by byl člověk zároveň redukován pouze na průsečík ekonomických a sociálních faktorů. Clověk jako ostře ohraničená osobnost navíc ve Frommově pohledu vlastně není cílem: je jím snaha o vlastní sebepřesažení v harmonii se vším, co jest.

Pokusíme-li se shrnout tento krátký exkurs, nabízí se vážné varování: člověk, který nedbá "tajemství svého srdce", který nerozvine smysluplně svůj vztah k celku světa v aktivním biofilním projevu na pevném základu své charakterové podstaty, zůstává podvyvinutý a jeho neuspokojená touha po naplnění života se snadno obrací destruktivním směrem. Člověku není vrozen nějaký záhadný pud z říše Zla, ale velmi reálná a znepokojivá možnost být nelidskou bestií.

10 Fromm (1997b: 28-31). Srv. Fromm (1992: 42): „Láska je produktivní činnost. Zahrnuje v sobě starat se o někoho (nebo o něco), poznávat, reagovat, potvrzovat, radovat se: a to at' jde o člověka, strom, obraz, myšlenku. Znamená to probouzet k životu, obohacovat ho." 


\section{Literatura}

- Fromm, E. (1997). Anatomie lidské destruktivity. Můžeme ovlivnit její podstatu a následky?. Praha: Nakladatelství Lidové noviny.

- Fromm, E. (1993). Budete jako bohové. Radikální interpretace Starého zákona a jeho tradice. Praha: Nakladatelství Lidové noviny.

- Fromm, E. (1967). Člověk a psychoanalýza. Praha: Nakladatelství Svoboda.

- $\quad$ Fromm, E. (1969). Lidské srdce. Jeho nadání k dobru a zlu. Praha: Mladá fronta.

- $\quad$ Fromm, E. (1992). Mít nebo být?. Praha: Naše vojsko.

- Fromm, E. (2004). Obraz člověka u Marxe. Brno: L. Marek.

- $\quad$ Fromm, E. (1997). Umění milovat. Praha: Nakladatelství Josefa Šimona.

- $\quad$ Funk, R. (1994). Erich Fromm. Praha: Nakladatelství Lidové noviny.

- Lövy, M., M. Buber, E. Fromm, (2001). Mesianismus a utopie v židovském evropském myšlení mezi dvěma válkami. Česká metanoia, 29-30(2001), 15-26.

- Machovec, M. (1995). Fenomen X v díle Ericha Fromma. [Referát ze sympozia mezinárodní společnosti Ericha Fromma v Praze v březnu 1995]. Edice Tvary,16(1995), 21-32.

- Štampach, O. (1999) Křest’ansko-židovské vztahy jako součást mezináboženského dialogu. In kol. (Ed.), Dialog křest’anů a židů (pp. 270-274). Praha: Vyšehrad. 
Časopis Envigogika vydává Centrum pro otázky životního prostředí UK. Vývoj časopisu je podpořen projektem OP VK Mezioborová sít udržitelného rozvoje.

Více najdete na internetových stránkách projektu mosur.czp.cuni.cz
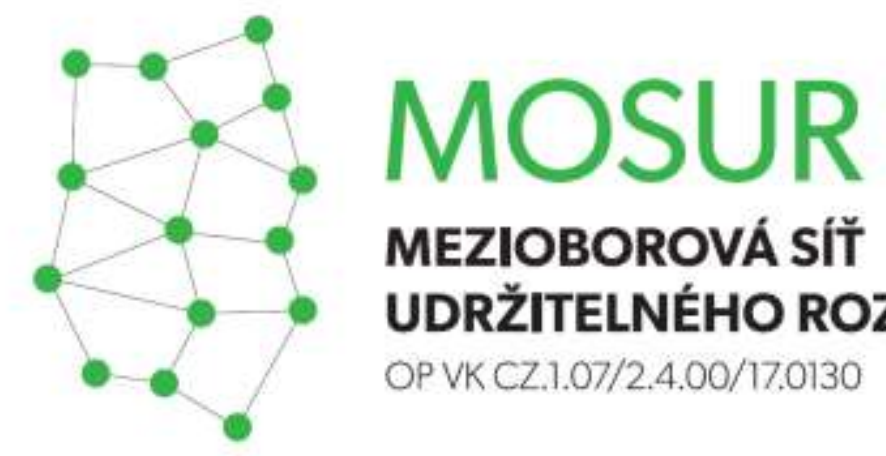

\section{MEZIOBOROVÁ SÍT} UDRŽITELNÉHO ROZVOJE

OP VK CZ.1.07/2.4.00/17.0130
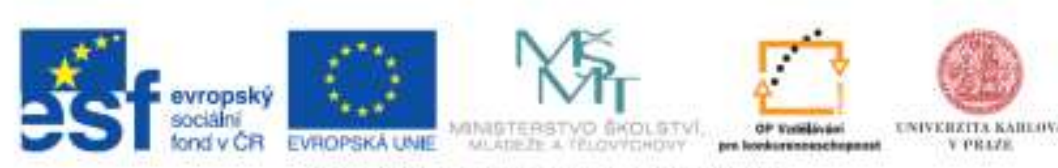

INVESTICE DO ROZVOUE VZDELAVANI 